\title{
A movement against the violation of rights: Estrada do Engenho resists
}

\author{
Um movimento contra a violação \\ de direitos: a Estrada do Engenho resiste
}

Nino Rafael Medeiros Kruger [I]

Caroline Krüger [II]

Cristine Jaques Ribeiro [III]

\begin{abstract}
The article discusses the guarantee of the right to housing starting from a reflection on a Public-Interest Civil Action aimed at the removal of the Estrada do Engenho community, in the municipality of Pelotas (Southern Brazil). Based on a movement rooted in the critical dialectical method and on militant research, the State's action is problematized, and the history of the community, the transformations that have taken place, and the tactics developed by the real estate market and the government are recalled. The article also questions the historical production of excluding rationalities and the problems arising from the poor management of public policies. As a result, collective work is developed and lines of action are built, enabling the destabilization of the process, protecting and preserving the ways of living of the local community.
\end{abstract}

Keywords: right to housing; housing public policy; resistance; Pelotas; Estrada do Engenho.

\section{Resumo}

Este artigo discute a garantia do direito à moradia a partir de uma reflexão sobre uma Ação Civil Pública (ACP) voltada à remoção da comunidade da Estrada do Engenho, no município de Pelotas. Com base em um movimento enraizado no método crítico dialético, tendo como esteira a pesquisa militante, a ação do Estado é problematizada, e rememoram-se a história da comunidade, as transformações ocorridas e as táticas desenvolvidas pelo mercado imobiliário e pelo poder público. Questionam-se, ainda, a produção histórica de racionalidades excludentes e os problemas oriundos da má gestão das políticas públicas. Como resultado, um trabalho coletivo é desenvolvido e são construídas linhas de ação, possibilitando a desestabilização do processo, protegendo e preservando modos de habitar da comunidade local.

Palavras-chave: direito à moradia; política pública de habitação; resistência; Pelotas; Estrada do Engenho. 


\section{Introduction}

This writing is the result of a work that has been developed since 2016 in the city of Pelotas, state of Rio Grande do Sul (RS). In which, originally a group of Architecture and Urbanism students and Social Service researchers, bound to a Social Policy and Human Rights program, had been working on mapping the areas of occupation identified by the municipality as irregular. They began to monitor and provide technical assistance to a community that had been threatened by a housing removal process filed by the Federal Prosecution Service (MP), which began in 2008 .

In this context, Civil Class Action (Ação Civil Pública - ACP) n. 022/1.14.0007280-6 (Rio Grande do Sul, 2016) was aimed at removing the community resident in the Estrada do Engenho corridor. The lawsuit had been in court for eight years and a Conduct Adjustment Agreement (Termo de Ajustamento de Conduta - TAC) was drawn up and signed by the mayor at that time and the prosecutor of the MP, in which they had committed and dated the housing removal, without ever having heard the community residing in the location that had become the target of an action for violation of rights.

The approach of these researchers to such a context took place at first, in order to understand the process that unfolded over the territory inhabited by the community. Nevertheless, they had encountered a total lack of information regarding the legal action by the threatened group, in which the families only knew the date set as the limit for their stay in the place-November 15, 2017.
This situation led the researchers to organize a technical-social and legal support team to a better understanding of the question raised, in order to enable the community with information for seeking the guarantee for the constitutional rights of the threatened group. ${ }^{1}$ This process took place through the weekly monitoring of the community, visits where were worked from listening and remembering the facts that led the community to occupy the territory, their memories, their relationship with the city, the links established with/in the territory, and the processes of significance produced. In this way, ways of living ${ }^{2}$ belonging were perceived, a situation that led to reflection on the development of strategies aimed at guaranteeing the rights of the community.

A semi-structured questionnaire was built firstly, which was applied to the 56 families living in the area. Through this questionnaire, the socioeconomic conditions of the community and the infrastructure of each family were recognized and the information that had been collected from the exchanges and listening was confirmed.

Following the information accessed by the questionnaire that was provided, meetings were held where the focal group technique was worked (Image 1). Through this technique, a researcher accompanied by his work group (in this case, an interdisciplinary team composed of four members), and groups of ten residents representing their families, the target public of the first stage of the research, met in the same environment for a previously agreed period.

With the dialogue and discussion produced, data were collected about the investigation. So that, through local people 
Image 1 - Focal group work with the community

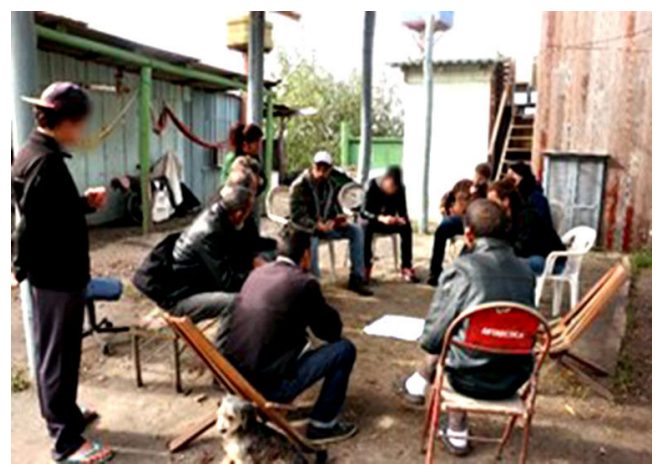

Source: Estrada do Engenho (2017).
Image 2 - Public inquiry about the local people removal

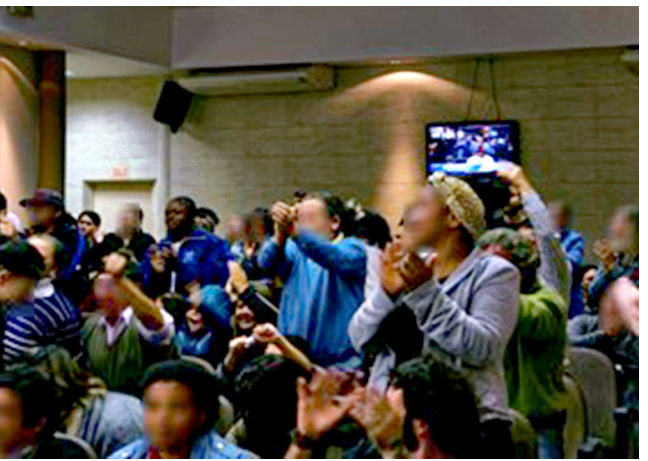

Source: Estrada do Engenho (2017).

The research has become a strategy to approach prosecutors, and a means to access information about the legal process. It is also an instrument for mobilization and denunciation of the violated rights, and a tool for action within a broad spectrum of critical reflection (Netto, 2011).

Thus, to understand how the relations of production and appropriation of urban space in the capitalist system have been developed, a militant research was created. This research perspective allows researchers to share and participate in the socio-political project of their field. Where, abandoning the position of observers, they can become agents of transformation. Involvement in the enrichment of the research process, where there is the possibility of recognition and horizontal construction of knowledge with the agents involved in each stage of the process (Cunha; Santos, 2010).

Based on an analysis of the content of the $A C P$, the juridical process had as a lens for observation of the complex reality posed. 
Thus, the origins of the disputes placed over the territory were recovered in the history of the community. Without, however, attempting to exhaust the reflection or the discussion process on the theme worked on, but seeking the transformation of the situation presented in the observation of movements and conflicts structuring the dialectic process (Netto, 2011). In problematizing the possibility of instrumentalizing the ACP in its approach to a multiple reality, with historical and documented incidence of diverse actors and interests.

\section{A necessary debate}

Promoting this discussion in the academic field is attained through the comprehension that the university as a producer of knowledge is a political space of conflict between social forces (Papaléo, 1991), a universe that produces knowledge validated as scientific that "has been currently evoked by those who intend to reduce policies [...] to mere technical solutions" (Acselrad; Mello; Bezerra, 2009, p. 31). These are considered to be necessary to confront, through the production of resistance that starts from the recognition and/or production of new knowledge capable of banishing exclusion, at any level.

For this reason, the reflections exposed here carry the restlessness of another paradigm of knowledge production. Based on the movement as the foundation for the development of reflexive processes, which are the search for the association of the experiences from social up to academic production. In tension, recognizing in the conflict the possibility of greater openness to the working class and to historically marginalized groups, in the participation of the processes of social transformation, bringing an effective contribution to change the reality exposed, markedly unequal (Bringel; Varela, 2016).

This conflict is presented as a strategy to confront the processes of appropriation of urban space by the State, which aim to obtain maximum profit through the expropriation and exploitation of men and nature, producing a "model of social injustice," which is faced here by those who oppose the current structure that benefits small groups (Nigro, 2007, p. 17).

The great challenge of the work in this context is to face the understanding of the transversal social structure, and act in order to diagnose where these processes are established, and materialize practices that corroborate with it. For, understanding that the socio-spatial division of cities was defined by rationalities inherited from the colonial process - which deny the absorption of the excluding mentality of those placed in vulnerable situations by urban and housing policies - the diverse territories became areas of articulation of the dehumanization of subjects, exposed to practices of multiple exclusions, and may have, according to "judgment", changed the course of their lives. Insurgents, groups that were placed before such situation resist, and thus, from lived experience, subvert paradigms, produce other epistemologies, new knowledge.

In this regard, the theoretical debate built on the relationship between researchers and the community, aligned with actions of practical mobilization, made this reality public. It became apparent that the territory (Saquet; Silva, 2008) under study, located on the 
shores of Canal São Gonçalo, was the object of dispute after having aroused the interest of the real estate market, on the rise there (Idealiza, 2014).

In this context, the real estate market began to impose constructions of large and varied real state projects that transformed the region, and made it a place of confluence of multiple interests and conflicts (Filho, 2017), placing in confrontation over the locality distinct ways of living, characterized as civilizational projects in practical and theoretical opposition. This strategy makes the image and the idea of the citadins - inhabitants of the city as a whole, with rights and duties to the city-disappear, reducing citizenship to the citoyens - those to whom the State recognizes the status of bearers of rights (Lefebvre, 2001).

In the meantime, the first way of living is characterized with the concept of polis, which translates as a place of encounters and confrontations that materialize life in the city (Vainer, 2013). This concept, placed in relation to the territory in focus, allows its apprehension as a space where distinct groups meet, building modes of existence, exchanges and integration with the environment, recovering the idea of citadins. The second is recognized as a city, and is characterized as a project that materializes in the spaces the mercantilization, objectification and submission to the market and private economic interests, excluding those who were previously unable to compete in the market of the cities (Vainer, 2013), and concretizes the idea of protection of the citoyens.

The studies, research and theoretical problematizations, aligned with the social action of the agents, made it possible for the multiple interests in dispute to be reported by the press (Cogoy, 2017; Munaretto, 2017; Coll, 2017). A petition presented by the group was accepted by the person responsible for judging the process, making the community part of it and enabling the problematization of issues related to the territory to be made in court.

Therefore, the reflection was needed on the roots of the problem and the actions of the State in the face of the expansion of the real estate market, a situation that was aggravated by the Civil Class Action ACP. The lawsuit filed by the Federal Prosecution Service (MP) against the Municipal Government accused the latter of negligence in inspecting occupations in Permanent Preservation Areas (APPs). And it framed the territory to these terms, imposing penalties on the resident families, not on the MP. The removal of the community was demanded on the grounds that it was in an APP, causing damage to the environment and being at risk. A problem widely addressed in the literature on environmental justice, where those causing the damage are not held responsible, with the burden falling on groups placed in a situation of vulnerability (Acselrad, 2010).

Collectively, studies have been undertaken and problematizations have been built on this panorama, stimulating reflection on this reality in the face of the ACP. Thus, research was carried out in alliance with the community, committing to analysis and reflection to understand and unveil other processes that could be hidden in state and legal practices. These historical processes reflect the deepening socio-environmental and territorial inequalities in the locality, a cadre also aggravated at the national level (Acselrad; Mello; Bezerra, 2009). 
A contribution in a theoretical and practical way has been made to the construction of strategies capable of transforming the concrete reality. The research was developed from a socially committed perspective, based on the production and reproduction of social contradictions in a politically positioned manner (Bringel; Varella, 2016).

\section{At the origin of the city the roots of exclusion}

In order to understand how the dispute processes that unfold over the territory under analysis was reached, it is pertinent to develop a brief remembrance of the origin of the city of Pelotas and the genesis of the Estrada do Engenho community. It is worth mentioning that this remembrance, built together with the community, seeks to situate the historical role of the territory with regard to local urbanization process. This perspective makes possible the observation of the city as a work, which is built and consumed, and from which its inhabitants are objectively and subjectively appropriated - a social construct, fruit of social-spatial inter-relations, and a commodity for capitalism (Kowarick, 1993).

It is conceptualized that the place from which the families were to be removed, since their origin, presents itself as a space where groups excluded from state protection - in principle black slaves, and later, groups of workers in extremely vulnerable situations met to live and develop their work activities, even before the constitution of the city. Thus, before being elevated to parish in 1812 , in the then sesmaria de Pelotas, the first camp of the district was formed - the Passo dos Negros (Black Pass). It was renamed a century after Estrada do Engenho (Gutierrez, 2001).

The first references about the municipality, dated from 1758, relate its origin to the Estrada do Engenho. In the year cited, the then governor of Rio de Janeiro, Count of Bobadela, made the donation to Tomás Luís Osório of sesmaria, which was divided and originated the first estancias that hosted the charqueadas that started the city. This movement of territorial division was driven by the economic development coming from the supply of food, especially the charque (jerked beef) - an activity intrinsically dependent on black labor - was what gave rise to the Passo dos Negros (Black Pass), and from it the municipality (Map 1).

In this place, still at the end of the 18th century, the first wharf of ships was built, where the enslaved and goods coming mainly from Europe were received. This was the scenario that made the territory under analysis the main access door to sesmaria, where the tax collection station for the Portuguese crown was established, and from where the saladeril production was sold - a process developed according to Gutierrez (2001) for almost a century.

The historian Al-Alam (2017), writing about the origin and development of the city, points out that there was an attempt to found the city in this territory, where projects were developed aiming at greater population concentration. This was not accomplished due to the interests of Father Felício and Antônio dos Anjos, who were trying to sell land from their properties to the north of the place. About this fact, Gutierrez (2001), also points out that the problems generated by the waste 


\section{Map 1 - Passo dos Negros (19th century)}

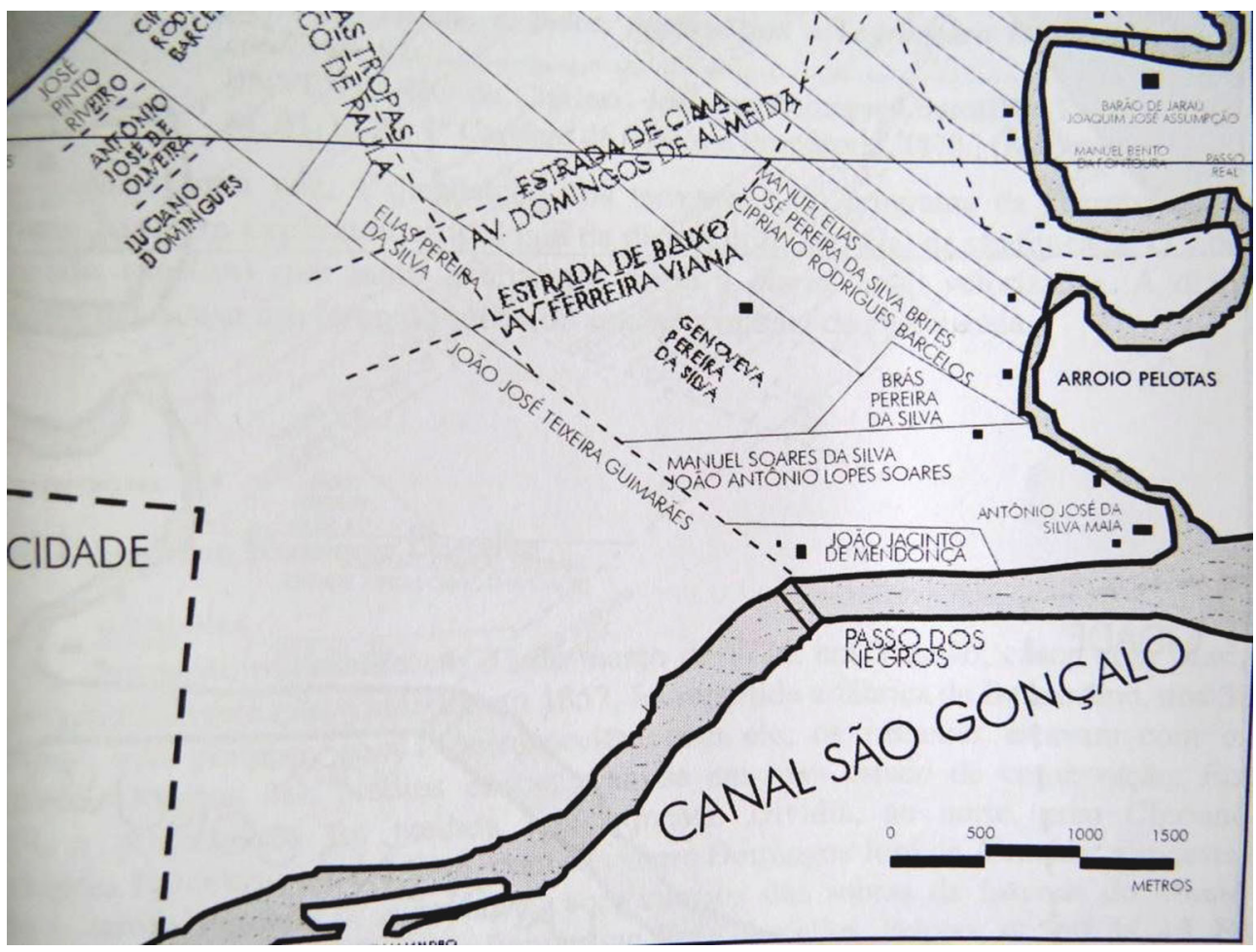

Source: Gutierrez (2001, p. 14w3).

of the charque production launched in the Channel that surrounds the territory, and the intense concentration of slaves that circulated in the locality, were used as subterfuge for the realization of the interests of the land owners. This situation prevented the first urbanization project developed for the city from progressing.

From these initial notes, it can be observed that in its origin, the city is related to a donation involving actors of great power and influence, having in its genesis private interests overlapping with the collective benefits. Historically, the Channel that permeates the city - where the Estrada do Engenho is currently located - was the target of the discharge of waste. This was initially a consequence of the first stage of development of the municipality, driven by the intense commercial activity based in this region, where the goods produced by slaves were controlled (Al-Alam, 2017), 
After this phase, with the city already consolidated according to the planning of the land owners, in the second period of local economic development, the activities are marked by the processing of rice. This activity marked the transition period between the 19th and 20th centuries, and again made the marginal space of the Canal São Gonçalo central to economic interests. On the banks of the Canal, the first rice milling company was built in the region (Rheingantz, 2004) - the Engenho São Gonçalo - also called Engenho Pedro Osório. The local morphology is changed and the territory is renamed: o Passo dos Negros becomes the Corredor da Estrada do Engenho (Defender, 2)

From the installation of the mill, the territory that was already marked by the presence of the black population, receives the addition of a village of workers that sustain the operation of the mill (Rosenthal; Gonçalves, 2014). A few decades later, a fishing village was established there, which ended up not being benefited by the urban infrastructure development movements that occur in expansion in the north of the city.

Map 2 - Localization of Estrada do Engenho on the road map (2008)

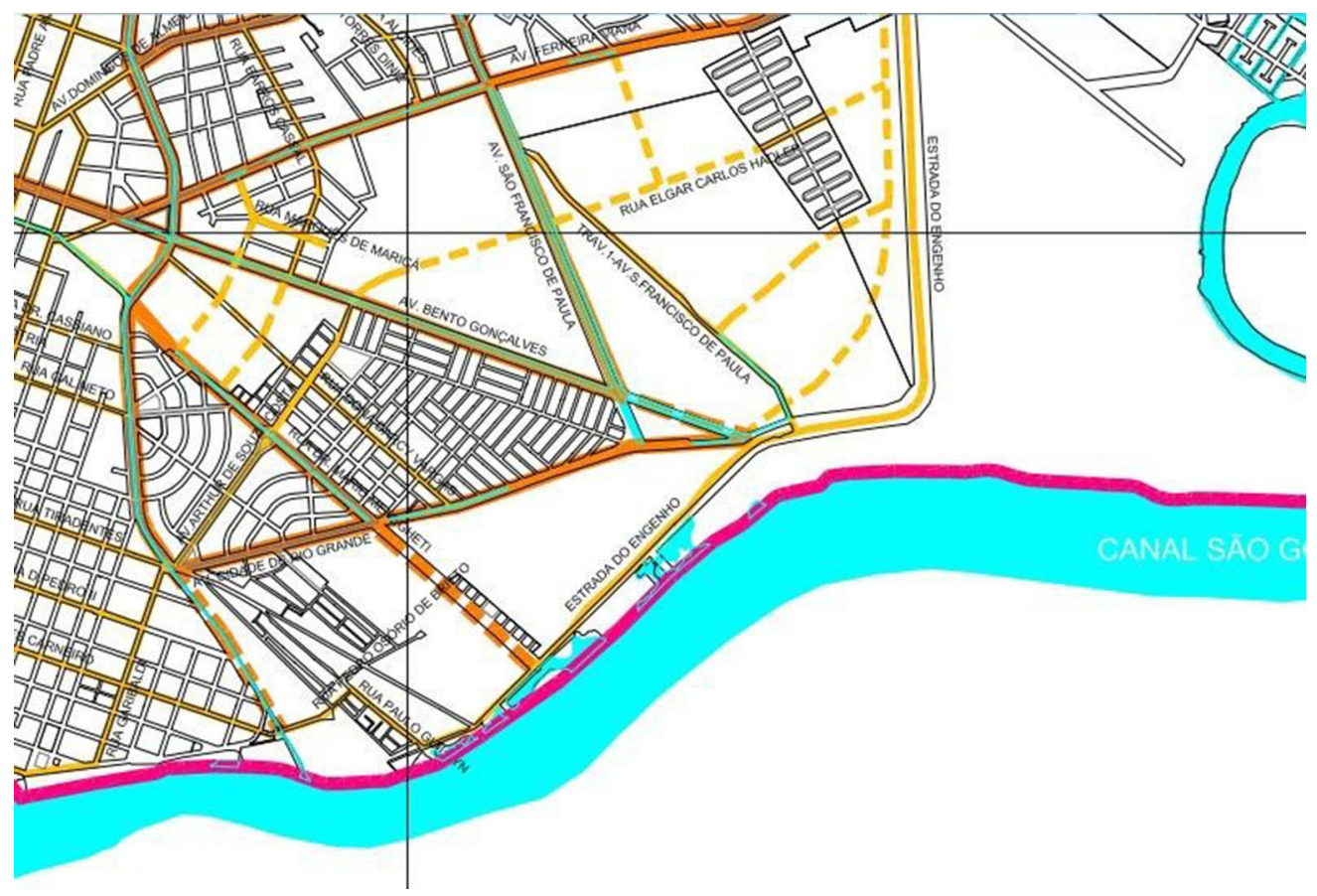

Source: Pelotas (2008b). 
This is because, at the beginning of the 20th century, the territory on the banks of the Canal was considered a region not conducive to housing construction. Without value to the market, it becomes in the terms of Martins (1997) a space of marginal, unstable and precarious inclusion.

Thus, the territory was inhabited by original communities, traditional groups and those unable to access the formal land market for two centuries (Gutierrez, 2001). And unlike the valued areas in the city, for which investments in infrastructure works were developed, the Estrada do Engenho was "forgotten", and the spaces that consubstantiate the social hierarchy were created, shelters for the heirs of alienation (Maricato, 2015), spaces of operation of accumulation by urban dispossession (Harvey, 2005).

In order to remain on the banks of the Canal, in this territory lacking public investment, the different groups that occupy it have ended up developing particular ways of relating to the environment, building houses with their own technologies, consistent with their relationship with nature and financial resources, related to their work activities, focusing on their way of living. In this way, enslaved people who were once locked up in senzalas became workers thrown into slums, waste pickers and service providers of all kinds, to which were added fishermen dependent on stilts -people from outlying areas, excluded from the city and the formal labor market.

Forming an area of potentialization of the processes of exclusion (Martins, 1997), the territory was consolidated as a region for housing of those placed in a situation of extreme vulnerability, about which the real estate market and builder has no interest. In the territory starts to operate the liabilities of the unequal and combined urban economy (Oliveira, 2013). While the noble areas receive the bonus of the urbanization process, Estrada do Engenho operates the burden of a dynamic in which the advanced aspects of the capitalist mode of production are nourished by the production of forms of backwardness, which unfold and feed back simultaneously.

The denial of the benefits of urbanity and access to the city creates the negative the non city - where infrastructure, equipment and services are lacking, sustaining one of the intrinsic contradictions of capitalist modernization: the negative of development that feeds back and drives the latter. The (in)production is strengthened in the lack of infrastructure to potentialize exclusion (Martins, 1997), deepening inequalities (Oliveira, 2013).

Until the 1970s, no urban action to improve the conditions of existence of the population of Estrada do Engenho was developed, only sparse works of low or no quality. The first project planned to qualify the territory appears only in 2001 (Ribeiro, 2017). It is worth mentioning that this project does not count with the presence of the population historically resident in it, as can be seen in Image 3.

However, this project was not executed (Image 3). The exclusionary rationality that it expresses and its influences will be evident in the implementation of the III Municipal Master Plan (Plano Diretor Municipal - PDM), which occurred seven years later. In this plan, it will be possible to observe issues that relate the interests of the market to those of the MP and, of ACP. These being responsible for triggering conflicts over the territory, as will be discussed specifically below. 
Image 3 - Project of requalification of São Gonçalo river channel

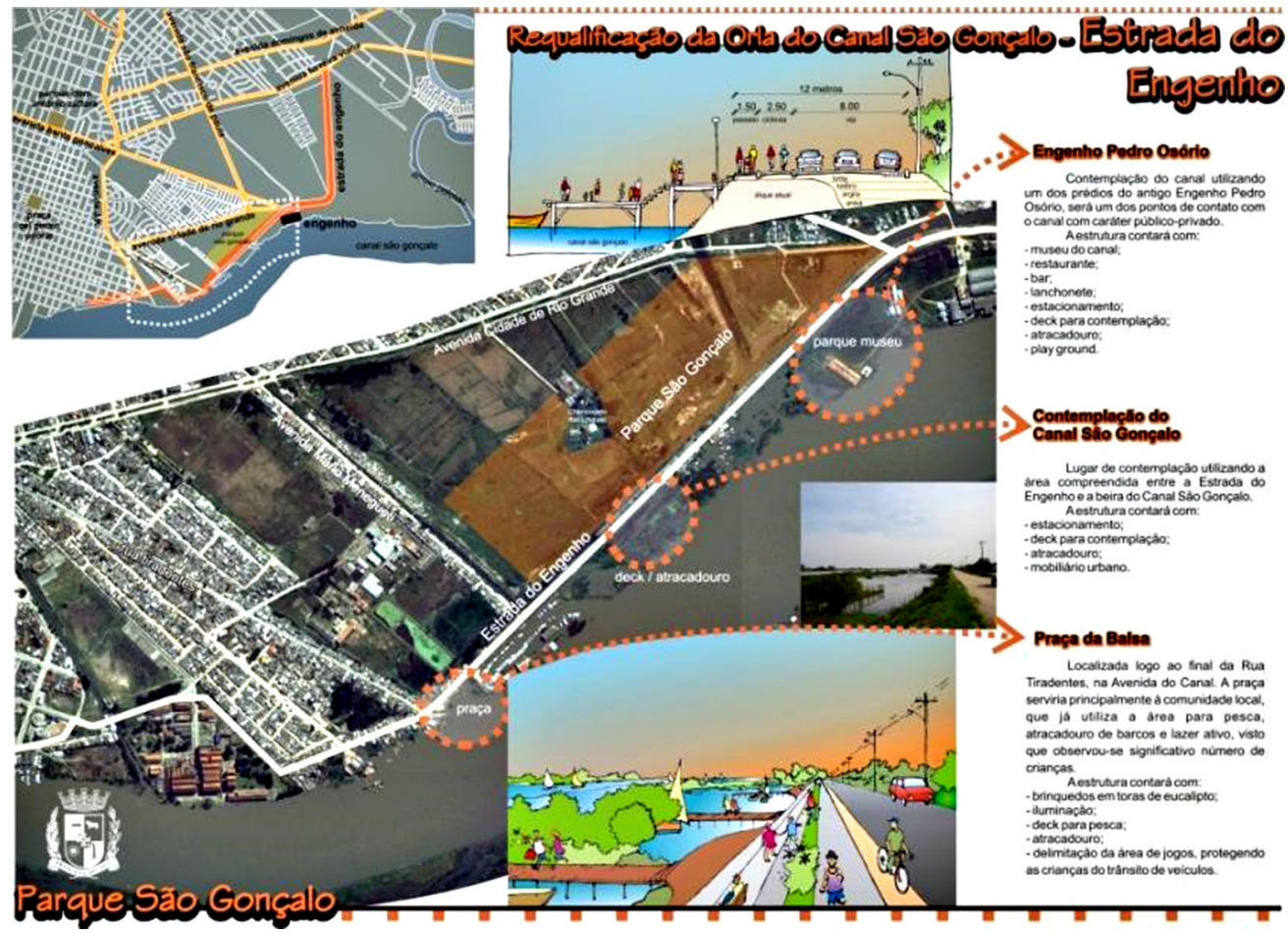

Source: Ribeiro (2017).

\section{When the air changes: the III Master Plan and the market interest}

One of the historical management marks in Pelotas is the development of actions to substantiate market interests. In legislation of 1881, which deals with the demarcation of the urban perimeter, it is possible to glimpse such strategies. In this strategy, in order to meet the interests of the industrialists who wanted to place workers in working-class villages, the construction of slum tenements on the outskirts of the city center was prohibited. As a result, the main housing model of the workers was eliminated, and the housing model that lowered wages, or expulsion to areas without infrastructure, was imposed (Moura, 2006).

From the late 19th century to the first decades of the 20th century, local newspapers present reports that expose the tension of builders for the municipality to benefit the development of their projects. The market demands that arose ranged from the supply of land and the development of legislation to the execution of public works aimed at facilitating processes and meeting the interests of elites (Moura, 2006). Thus, the State began to execute measures aimed at a greater subjection of workers to entrepreneurs, through strategies that enable 
the increase of accumulation. A process of "industrialization at low wages" with an equivalent in a low-wage urbanization (Maricato, 2015, p. 27).

This situation, although varying according to macro-structural economic issues, has not changed over the years. Since 1968 with the passing of the I PDM (Pelotas, 1968), which was replaced in 1980 by the II PDM (Pelotas, 1980), the issue has worsened. This is because the planning of actions aimed at the materialization of even bigger processes of social exclusion are spent. Precarious territories are developed, concretizing the maxim of poverty binding, the deprivation of basic urban infrastructure, creating territories where the stigmas produced in the 19th century were strengthened (Kruger, 2018).

The III PDM (Pelotas, 2008), guided by the Statute of Cities (Brazil, 2001), has registered important advances in the direction of guaranteeing rights to the municipality's inhabitants. The document reinforced the need to adopt measures aimed at fulfilling the social function of the city and the property. It acknowledged the multidimensionality of the municipality's potentialities, and reiterated the guarantee of the right to the city as "the right to urbanized land, housing, environmental sanitation, infrastructure, transportation and public services, work and leisure" (Pelotas, 2008 , p. 2). He also emphasized the importance of democratic and participatory management in the implementation of territorial policies, and in six different articles specifically addressed the territory of Estrada do Engenho, explaining the procedures that should be developed for its integration with the city.
In article 88, paragraph 2, he emphasized that one should "avoid the expulsion of its residents, through the use of legal instruments" (Pelotas, 2008, p. 36). Then, it acknowledged the territory as a Special Area of Social Interest (Área Especial de Interesse Social - AEIS) type 1 , which is located in "an area of environmental preservation, occupied by low-income population" (Pelotas, 2008, p. 38), classifying it as an Occupied Permanent Preservation Area (Área de Preservação Permanente Ocupada APPO), where the land use property should be adapted to its social function.

In articles $60,87,88,90$ to 93 , the legislation presents a series of actions that should be executed in the territory. Pointing to strategies for generating work and income; land regularization; development of urban infrastructure; availability of resources for housing recovery; environmental recovery of degraded areas, etc. (Pelotas, 2008). However, the non-execution of these actions opened the possibility for the market to design real state projects for the site, counting on the facilities established by law.

In this sense, the III PDM discoursed about the need to transfer the centrality of the municipality to the region of Estrada do Engenho, treated as the region of São Gonçalo. It claimed that the urban center of Pelotas (near the region) should be preserved (Pelotas, 2008). These issues added up, focus on a process of valuation of the territory by the market, in order to develop a set of real estate and commercial enterprises in the region. Works materialized without respect to the environmental legislation in force, as can be seen in Images 4 and 5. 
Image 4-june of 2010, territory before the soil filling of swamp areas

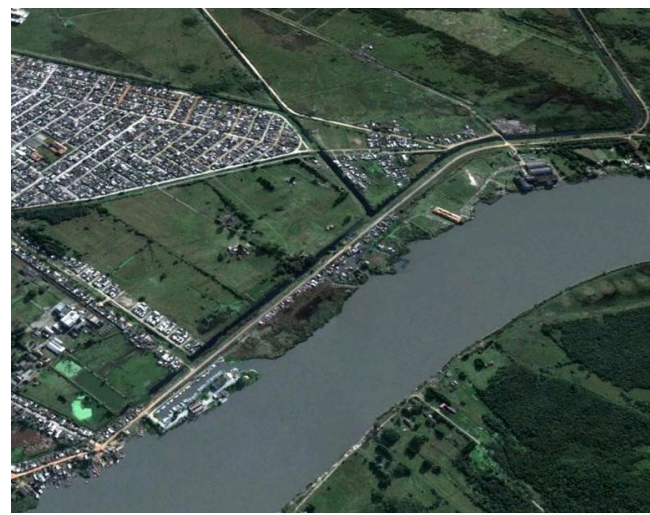

Source: Google (2017a).

According to state environmental legislation, in article 155, paragraph 1, areas along rivers or water courses, mangroves, marshes, springs and swamps are considered APP (Rio Grande do Sul, 2012), and could not be landed. However, authorizations were obtained for the construction of the projects.

Parallel to these processes, which began to occur after 2008, was the denunciation to the MP regarding the occupation of the APP area in the territory, by "groups that would be causing environmental damage". Thus, the first factors pointed out in the ACP did not relate the construction of large enterprises in the context of conflicting interests. Rather, they weighed on the community - families who historically inhabited the territory

It was then observed that the legislation used to criminalize the historical occupation was the same neglected as regards the soil filling of the swamps for the new buildings. Thus, it became a problem that the legislation that underlies the ACP was being used to facilitate
Image 5-october of 2016 territory after the soil filling of swamp areas

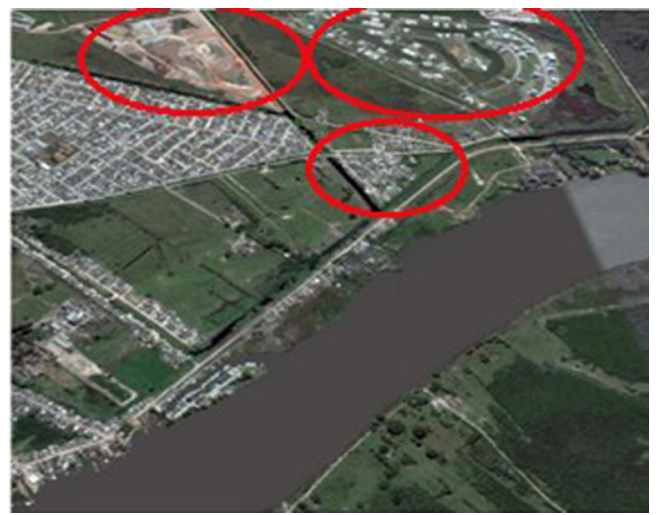

Source: Google (2017b).

the materialization of actions of exclusion on the groups that inhabit the place, thus enabling or operating an urbanistic surgery, i.e., the removal of those who were historically excluded in previous urbanistic processes.

It is important to reiterate that this situation demonstrates the reality of many other communities scattered throughout the country, which have the access to housing and work denied under the demands of a market driven by historical structures, which reinforce the conditionalities imposed by public policies for access to rights. This is a reality that guides the Brazilian context, making itself the rule, since it concerns the largest portion of the country's population (Maricato, 2015).

In this scope, by deepening the analysis of the ACP, from the analysis of content (Bauer, Gaskell 2012) - a methodology that enables the construction of connections with the proposed objective -, we sought to answer the question of research. This was related to the documents and legislation dealing with 
the history of the territory and its inhabitants. Thus, the researchers were led to an immersion in the problem lived by the community.

Thus, the path taken was to deepen the reflections on the complexity of the issues that involve the plot of urban relations in the territory, building possibilities to overcome the problem posed. The disputes expressed were constantly rethought in order to understand the appropriation strategies and their impacts on the territory and the population living there. By appreciating the dynamics as manifestations of the social issue ${ }^{3}$ - an argument for claiming equity in law enforcement - social legitimacy was sought for the struggles (Acselrad; Mello; Bezerra, 2009).

\section{Estrada do Engenho Resiste: a movement}

From the non-implementation of the statutes presented by the III PDM on the Estrada do Engenho to the lack of recognition by the ACP of the historical constraints imposed on the community, the conflicting interests created a catalyst that drove the expulsion process. Situations superimposed on the rhetorical justification of the legal process that the territory is an APP, in which the families living there would be causing damage to the environment and finding themselves at risk - the structure and principle of the ACP that justified the removal of a space targeted for mercantilization.

Consequently, a crime was attributed to the municipal government, accused of not supervising the occupation of the APP; and a penalty was imposed on the community.
It did not recognize the rapid increase in the occupation of the APP by the large real estate ventures, which did not dialogue with the historical forms of occupation. This covered up the actions of the market that produced marinas, high-income condominiums, and commercial enterprises, while at the same time accelerating the vulnerability of the community. Making the inhabitants a reflection of the deep social inequality materialized in the denial of the fundamental right to housing (Pereira, 2013), a series of apparently distinct movements that conflicted in the place.

Another movement is highlighted by $A C P$, which pointed to the increase in the number of families that have turned to occupation in the last decade. This is because the legal action did not recognize that this group was not able to enter the formal housing market, victimized by unemployment and an increase in rents, not achieved by the housing policies of the period - which should have the purpose of serving them - in the case of the My Home My Life Program (Programa Minha Casa Minha Vida - PMCMV), which turned the most profitable sectors to the market (Pinto, 2016; Kruger, 2018).

As a consequence, families not served by the program came to the area to secure housing and minimize their subsistence. This movement was denounced in the ACP, which does not separate historical resident families from the group afflicted by economic variations and the crisis, which sought housing in the area. Thus, the population found in an area of risk, as the lowest income families, are responsible for occupation and damage. Thus, those who are driven by financial valorization to these spaces, groups and projects that do not dialogue with the 
pre-existing forms of life, which impose themselves and cause as much damage as the others, are protected. The MP is also protected, accused of negligence in dealing with the APP inspection, and responsible for the planning of the PMCMV that did not reach the priority populations, launching them into a process of aggravated vulnerability. These groups were not held accountable.

In these terms, many are the concealments, such as the socioeconomic profile and historicity of the distinct groups that occupy the territory, a structure founded on stratified relations of class and race. Obscuring that among those harmed by the ACP there are original groups such as: families of descent from slaves; workers who built the city through their work in the charque (jerk beef) and in engenho (rice mill). These populations were responsible for the economic development of the municipality until the mid20th century. Besides these, there are artisan fishermen who need the Canal to develop their work activity. And finally, those excluded from the formal labor market, unable to compete in the rental market, a group marked by the movement of financialization and elitization of the housing market - one of the main marks of this sector in the country (Boulos, 2015). Being necessary here, an opening to deepen this debate in the case of Pelotas, and introduction in this discussion of the extent of the local housing problem.

\section{Occupation and resistance}

In this item some notes will be brought about the areas of irregular occupation and housing production projects from the year 2008 in
Pelotas. Year of promulgation of the III PDM, of the availability of resources for the PMCMV (Galhardo, 2008), and the beginning of the ACP. Later, the information and its developments will be cross-referenced and related, of particular importance to the apprehension, as they are variables that substantiate the problematization about the processes of exclusion and territorial mercantilization spent in recent years on the municipality. $A$ panoramic view of the events with impact on the case of Estrada do Engenho is created.

It is based on the survey conducted between 2008 and 2009 by the municipality's land regularization supervisor, Jorge Alves, presented at the City Council in 2013, which reports that Pelotas had 156 areas of irregular and clandestine occupation (Alves, 2014). These areas are characterized as "areas in which, although approved by the City Hall and other organs [...] when necessary, physically they are not executed, or are executed in mismatch with legislation or with acts of approval," regarded as areas that "did not obtain the administrative approval or authorization of the competent organs, including not only the City Hall, but also State and Federal entities" (Alves, 2014, p. 3).

The study points out that in these 156 areas there were on average 72 plots of land in each one, so it would be approximately 11 thousand plots of land. In each of these, there were about three people per family, and numbers close to 390 people per area. Thus, there were more than 60 thousand people living in irregular and clandestine areas. In addition, data from the Brazilian Institute of Geography and Statistics (Instituto Brasileiro de Geografia e Estatística - IBGE) census for Pelotas in 2010, which coincided with the 
survey, show that the city had about 130,000 housing units and 328,275 inhabitants. Crossed the numbers, it can be seen that more than $8 \%$ of the housings in the municipality were irregular and in these areas were more than $18 \%$ of the population (IBGE, 2017).

In 2013, the city's Local Social Housing Plan (Plano Local de Habitação de Interesse Social - PLHIS) was launched. This study highlighted a deficit of 13,598 homes in the city, a calculation that included makeshift shelters, precarious, cohabitation and families with excessive rent (Plhis, 2013a; Plhis, 2013b). It became visible what the housing problem was, since the deficit was more than $10 \%$ of the dwellings. Where, of this percentage, more than $80 \%$ was a qualitative deficit, i.e., existing housing, but in an irregular or clandestine situation - housing that needed documentary regulation, urban infrastructure, equipment and services.

Four years later, in 2017, a new report points out that between 2013 and 2016 the land regularization of 10 allotments was carried out, and that another 10 would be in process, figures that are equivalent to a little more than $6 \%$ of the 156 irregular allotments in 2013 (Alves, 2017). This regularization was done only with regard to the documentary issue, so that only property titles were delivered, without the installation in any of the locations of equipment and services. This situation expresses the understanding of land regularization and the perspective of guaranteeing the right to housing of the PM.

Continuing the analysis of the surveys done in 2013, it is pointed out a deficit of more than 13 thousand units (PIhis, 2013a), about 11 thousand were makeshift shelters, precarious residences, etc., dwellings that needed regularization, improvements and investment in the territories in equipment and services (Alves, 2014). According to Pinto (2016), the author who presents data from the Caixa Econômica Federal Housing Representation, these actions were not taken (Rehabpel, 2018), and there remains an urgent question: why did the MP adopt as a policy the construction of new housing units, to the detriment of regularization?

Continuing the analysis, between 2013 and 201641 PMCMV projects were delivered, through which 7,665 housing units were produced, corresponding to $56 \%$ of the municipality's housing deficit (according to the deficit pointed out in 2013), built with public resources. In addition, it is important to highlight that the changes promoted by the Ministry of Cities since 2003 in the housing sector, especially through the PMCMV, "were aimed at combating the housing problem for the low-income population" (Pinto, 2016, p. 55). However, according to the figures analyzed, this population represented more than $80 \%$ of the municipal deficit in 2013.

In addition, if instead of working the data from 2013 on, one analyzes from 2009 (2009 - 2016), year of production start through the PMCMV in the municipality, and data collection period of Alves (2014), the number of constructions goes from 41 to 60 , and the housing built goes to 11,919 (Pinto, 2016). In view of this, it can be seen that the housing production through the PMCMV should have ended the deficit of the lowincome population - the population for which the program was developed, according to its guidelines. In this problem, the population living on the shore of the São Gonçalo Channel, at Estrada do Engenho, is included. 
It is noticeable that from these analyses, the answers to the accusations made by the MP that weigh on the community of Estrada do Engenho emerge. In order to better highlight them, the MP's accusations are presented as quests:

- Why did the number of families occupying the territory increase? (a question that still goes back to the established discussion about the enactment of the III PDM)

- If expulsion of residents through legal mechanisms should be avoided, how did this situation come about?

- Why does the ACP require removal?

- Why the MP, which built the law of the III PDM, didn't oppose the MP? Or, why did the MP not demand the planning of the III PDM instead of demanding the removal?

- As in a scenario of high housing production, "aimed at low-income populations," is there a significant increase in occupations on Estrada do Engenho? (Rio Grande do Sul, 2016)

- In view of the high number of housing production and land regularization processes that have been developed, has the number of irregular occupation areas in the city decreased?

On the contrary, the number of occupations did not decrease, instead of that the irregular occupations went from 156 (between 2008-2009), to 162 (in 2014), reaching 205 occupations (in 2017 - last year of data update), where "more than 90 thousand people" reside in irregular areas, which represents "almost $1 / 3$ of the population" of the municipality (Alves, 2017, p. 26).

Thus, it is noticeable that in Pelotas the production of dwellings through the PMCMV could have ended the housing deficit for the low-income population. However, what occurred was an inversion of values in the act of materialization of the program, which turned to the most lucrative ranges and to the market, incurring in the increase of irregular occupations. This fact was verified not only in the municipality in question, but throughout the country (Boulos, 2015).

\section{Why resist?}

The increase in occupation on Estrada do Engenho followed the growth of occupations in the municipality as a whole. This situation can be explained by observing the beneficiaries of the planned housing policy in Pelotas, to which the areas considered as irregular are the negative from which the urbanization process is fed, and from where the relative urban surplus value is extracted. This issue is a part of the farcical orchestrated good that legitimizes the projects of dominant groups for the cities, creating false consensus, giving way to business interests, and not meeting the popular demands (Vainer, 2013).

The PMCMV was the main housing policy planned in the city in the last decades and through it more than 11 thousand new houses were produced (Pinto, 2016). Just like the $A C P$, the MCMV carries the discourse of solving structural problems, with specific actions, but only strategies to maintain the interests of elites, favored by public entities (Nabuco; Primi; Nabuco, 2014).

Influenced by private promoters, produced with low quality and high profitability, the impacts of (My House My Life Program - MCMV's property development in the city are remarkable. Even in the face of 
studies that pointed out the housing problem (more than $80 \%$ qualitative), the production was $76.49 \%$ for groups with income above 3 minimum wages. However, when divided by income group, $23,96 \%$ of the production was for group 3; $52,45 \%$ for group 2; and 23,59\% for group 1. These data represent, that besides a priority inversion on the public policy planning act, it occurred the prioritization of the most lucrative ranges for the market. Also pointing out why the lack of progress towards the solution of local housing problems. Instead of investing in land regularization and urbanism, it was opted for the production of new housing, through a process focused on serving the groups with higher income.

In addition, municipal laws were created and changed during the planning of the PMCMV in Pelotas, with the intention of favoring builders and private developers (Pinto, 2016), among them, Law 5.603/2009, which instituted the social interest housing program "Pelotas Decent Housing". This program made possible the construction of the largest number of dwellings within the PMCMV, without presenting addenda on their quality to the users, and bringing construction tax exemptions to their executors (Pelotas, 2009).

Another law sanctioned was the $5.963 / 2012$, specifically on December 28th, three days before the end of the mayor's mandate in the period (Pelotas, 2012). This law changed the urban perimeter of the city and allowed the production of houses totally without infrastructure, favoring the reduction and even the dispensation of green areas and areas of public use inside the developments, as it was previously provided by law, allowing construction harmful to the urban tissue (Kruger, 2018).
It is also noted that such an extension of the urban perimeter did not occur fortuitously, as it "made possible the design and construction of two of the developments belonging to the PMCMV" (Pinto, 2016, p. 225) in areas that go beyond the urban limits - demonstrating the influences of private developers on the evident legislation. These interventions were specifically aimed at facilitating profitability, as they impacted more than 11,000 housing units produced with public funding. However, the PMCMV did not even reduce the number of irregular occupation areas, making the processes even more complex.

In the city transformed into an economic subject, of a mercantilized, entrepreneurial nature, "the power of a new logic has been established, with which the direct appropriation of the instruments of State by private business groups is to be legitimized" (Vainer, 2013, p. 89). Through the provision of resources, the administration of zoning and land parceling laws, as well as the development of urban plans, the decision on the city's production was relegated to the State. Problems that, once visualized, structured the questioning of the statements made by the $A C P$, pointing out that the lack of supervision by the MP on certain processes was strategic. Similarly, the negligence in not planning the instructions provided for in the III PDM, which by not addressing the needs of the vulnerable population, established a ballast for the effectiveness and development of the ACP.

Consequently, by demanding the removal of the community living on the bank of the Canal São Gonçalo, without considering the complex plot that was developing in the city, especially in the territory, the legal 
process concealed the dehumanization and objectification of groups historically victimized by the silencing and neglect of the State. An action that reflected the materialization of processes of subalternization, criminalization and persecution of the community, making it possible for the heirs of a racist and elitist heritage to enjoy their bonus of exploitation social privileges.

This rationality, represented by the $A C P$, delimited the definition of subjectivities and physical spaces that determine the city, reproducing the model of advancement based on the interests of market agents, leaving a trail of exclusion and segregation that reinforce a predatory supremacy. In this respect, Image 6 demonstrates how a conservative modernization is developed over the territory. An updating of the old actions to perpetuate the unequal and combined model, reflecting the contradictions of the capitalist mode of production.

It is important to clarify that Image 6 was edited to visualize how the territory has been altered, from the appropriation of the urban voids found in it by the construction market, and the number of plots of land that are still without construction - areas that still allow the development of new projects. Also, through Image 6, it can be seen that the target community of the removal process occupies an area that delimits a boundary between the new developments and the access to the natural resources found. This appropriation establishes new milestones for the conflict, and the development of other problems:

Image 6-Real Estate Development of the last decade and urban voids in the territories

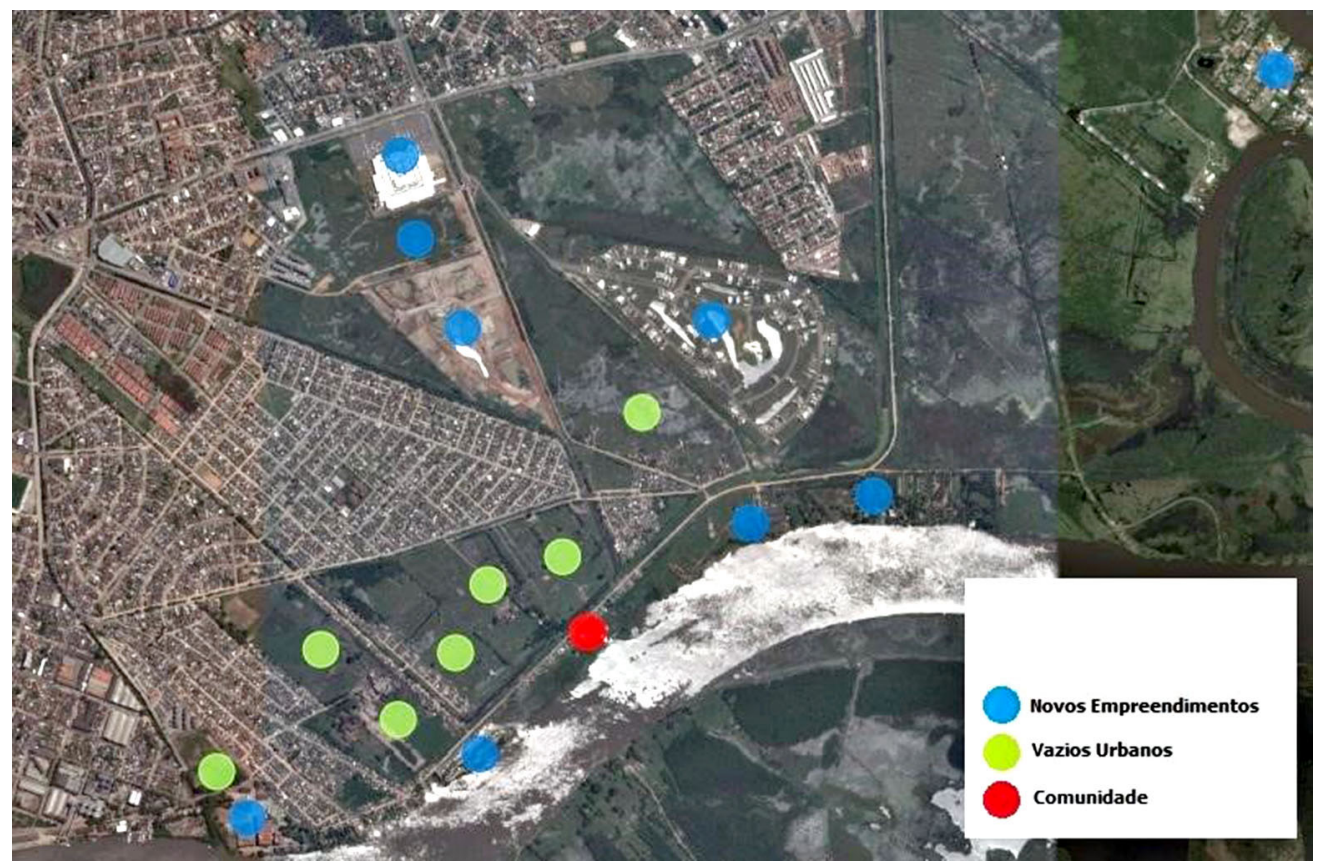

Source: Google (2017a, edited). 
- Since the area on the banks of the São Gonçalo Canal is considered at risk - as defined by the ACP - why is this only suit for the vulnerable population?

- Being made the execution of public policies programmed by the III PDM - specific to the site, dealing with the development of urban infrastructure, sanitation, etc., and pointing to the construction of specific projects in accordance with environmental legislation would the families threatened with removal continue to cause environmental damage?

- Returning to the historical remembrance made at the beginning of this writing, is not the Channel target of the discharge of waste in the course of history - first of the charque, then of the engenho - and today of all the groups that without the service of sewage collection reside in the territory? And who are the most affected by such contamination?

- Aren't the artisanal fishermen who need a balanced environment for the development of their work activities? And can't or shouldn't they be the greatest guardians of local biodiversity?

- Since the housing policies (PMCMV) are worked in a way that contemplates the priority populations and their development, and constitutional rights such as housing and work are guaranteed to these groups, why are they not contemplated and need to look for these areas in order to establish residence and develop unregulated, and need protection?

- Since the PMCMV is working in its scope, not only as a possibility for the construction of new housing, but as a powerful instrument for regularization of land ownerships of precarious settlements, could this reality not have been transformed?
- And last but not least, what should be the role of the MP in this situation?

On each of these complex questions new analysis and writing can be developed. However, what has been sought since the first approach to this reality, and which has become the objective of this project, is to safeguard the rights of the community. This attempt has become a tension for the non removal of the original and traditional communities, in the search for social protection and guarantee of the rights of the families living in the place (Pereira, 2013).

It is also understandable that the execution of the PCA within the previously established frameworks would cause irreparable damage to these groups and could leave the way open for the development of new processes and financial exploitation projects on the place. These projects, without benefits to the guardians of the territory, who would bear the burden of their exploitation so that private producer agents could obtain the bonus, retrofitting the rationality of urban development that has been the keynote in the country and that materializes in the cities (Boulos, 2015).

In the case at hand, the removal of the residents from Estrada do Engenho was prevented after a long journey of community mobilization, studies, research, alliances and denunciations. This process involved countless agents, technicians, researchers, and extension workers who transformed the defense of the community's rights into their objects of work. This joint effort and articulation allowed for the creation of diverse studies in the body of which this writing is found. Projects developed with the community, and presented to the 
responsible authorities after the residents and their support group began to focus on the process. Alternatives were produced to resolve the conflict, without the community's rights being neglected. Among the actions planned are: the requalification of the territory; the repair of housing; and the development of activities to improve working conditions and income, for fishermen and waste pickers.

Still in 2017, the problems and tensions made the community and its support group part of the legal process. Thus, the reflections produced were listened to and accepted, and resulted in a new TAC agreed upon. Thus, welcoming the alternatives presented, a new agreement was established among the entities involved. In this agreement, the MP committed itself to supplying material and developing infrastructure qualification works, and the MP made financial resources available for the construction of new dwellings for the community - an agreement made official on March 5 of this year (Rio Grande do Sul, 2020).

Image 7 - Celebration of the signing of the agreement between

State Prosecution Service and Pelotas City Hall ${ }^{4}$

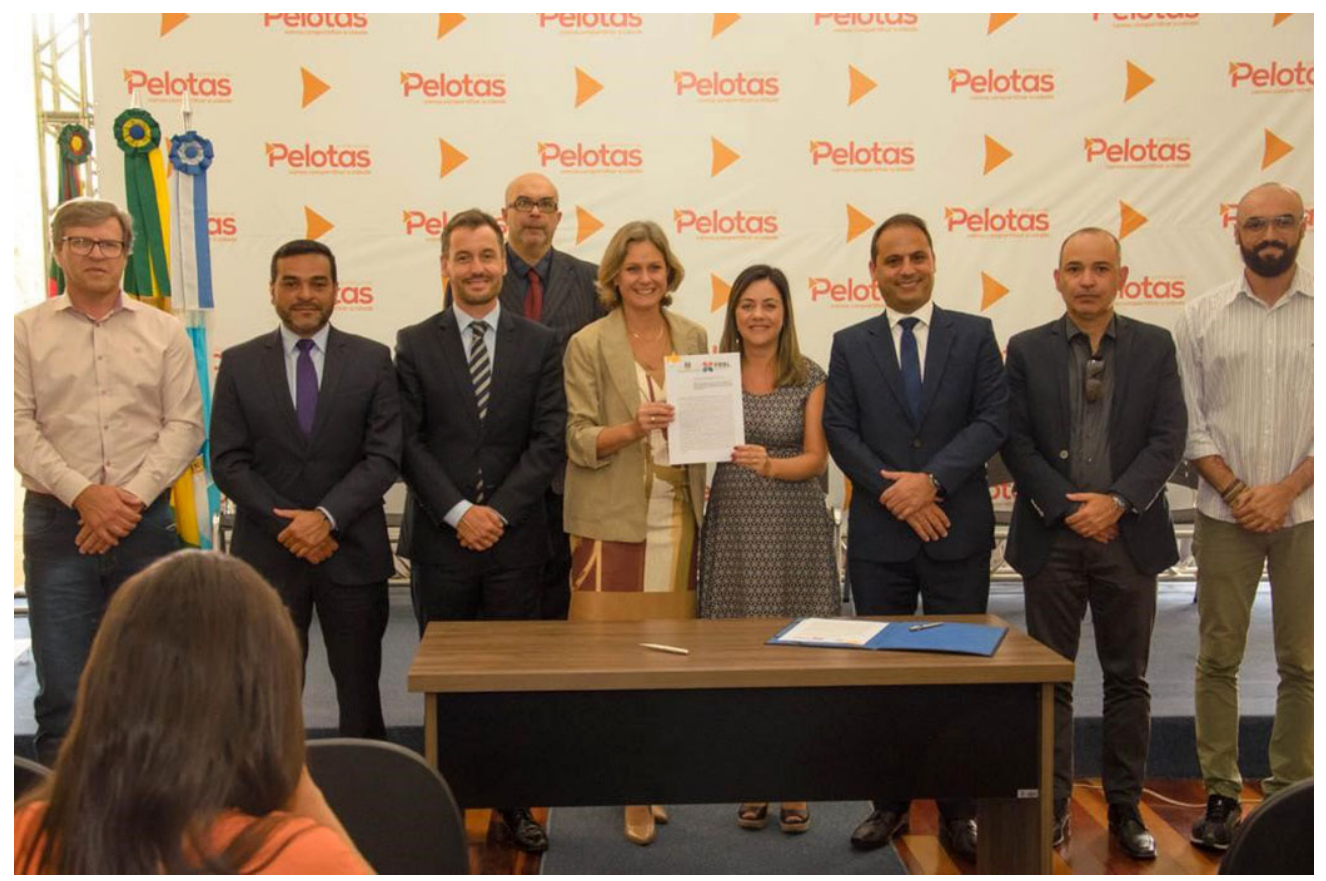

Source: Rio Grande do Sul (2020). 


\section{Final considerations}

The investigation led to the understanding that in ACP the historical processes that led the resident groups to occupy the space, and thus their relationship with the environment, were not considered. Nor was the legislation to protect the rights of such a community respected, which made the legal process an instrument to criminalize poverty and allow the prosperity of a sociability project based on the expropriation of those who are already poor.

In this way, the reflection on the specular interests of which the territory is a target $-a$ fact justified by the urban voids in the area (Image 6), and for which the MP had been developing projects without the participation of historically resident communities (Image 3) - reinforced the observations and the problematization of the State's actions in dealing with current legislation and legal instruments referring to the outskirts communities and those in vulnerable situations. This leads to a questioning of the factors that influence the processes and strategies for planning public policies, since these are materialized in models of exclusion potentialized by segregational processes, which aggravate the manifestations of the social issue.

The investigation of the strategies and actions developed through the ACP analysis has led to the understanding that programs and actions presented as necessary processes for the protection of life and the environment, by disassociating themselves from the material relationships that circulate them - such as manifestations of the social issue - can become instruments that deepen models of unprotection, territorial and socioenvironmental degradation that impact on and attack life, a contradiction that drives the capitalist system.

The tensioning and problematization of public practices with influence to such reality, related to the activities developed by construction agents around the territory, brought to light the interdependence of the processes. In other words, economic and political actions of influence over the exclusion and commodification of territory, which are linked to a very specific perspective of State management, in which the primacy of the market, which acts as a regulatory agent, is imposed.

This project, in its initial attempt to understand the relationships established over the territory, verified the process of mystification provoked in the execution of coordinated actions by public agents in mismatch with the social reality, and with the dangers of the ideologized use of legal statutes. It tried to become a tool of articulation and resistance to the violation of rights. In this way, it developed into a process of building emancipatory knowledge, capable of instrumentalizing researchers, collectives, social movements and the residents themselves (from Estrada do Engenho), for the search of protection and guarantee of the fundamental human right to housing.

In this way, concrete possibilities are presented to align academic research, from its methods and techniques to collective demands, treating the manifestations of the social question as a path to concrete transformations. This is when the university, a political space of conflict between social 
forces, an arena of production of knowledge, aware of its possibilities and limitations, overcomes the reduction of science to mere technical solutions and unites the struggles of social movements. Thus, the production and recognition of forms of knowledge that are strategies for resistance, survival, and confrontation with the logic put forward becomes possible. Broadening the debate on the right to the city, and the actions of the State in the framework of the capital, translating a tool for the development of other struggles, in a politically positioned manner, in favor of criminalized populations, groups that resist in the occupation of urban land, and that thus denounce the model of market-oriented planning, retro-fed by public policies that deny access to the right to exist.

It is also important to clarify that the report presented could portray situations in as many Brazilian cities as possible, given that it externalizes the rationalities that underpin the processes and model of urban development established over the nation, as well as the strategies of community resistance and militant researchers. Furthermore, it analyses how a PCA, constituted as a process, may fail to observe the multiple conflicting interests and previous historical relationships that instituted the problem and thus become a document of criminalization of victims. Legal processes are not established in isolation from their social, economic and political contexts, nor are actions taken by researchers.

Finally, it should be noted that it was the option to work in alliance with the community and build the strategies in solidarity, techniques and tactics to address the situation, which allowed the results to be achieved. Collective work was responsible for recognizing the need for tension over the PCA, making it possible to destabilize the process and achieve success in transforming the reality set, protecting and preserving ways of living, life, culture, history and local traditions. The Estrada do Engenho resists.

\section{[I] https://orcid.org/0000-0002-6181-4652}

Universidade Católica de Pelotas, Centro de Ciências Jurídicas, Econômicas e Sociais, Programa de Pós-Graduação em Políticas Sociais e Direitos Humanos. Pelotas, RS/Brasil.

contatorafaelkruger@gmail.com

\section{[II] http://orcid.org/0000-0002-6368-9138}

Universidade de São Paulo, Faculdade de Economia, Administração e Contabilidade, Pós-Graduação em Administração de Organizações. Ribeirão Preto, SP/Brasil.

carolgkruger@gmail.com

\section{[III] https://orcid.org/0000-0002-1660-8200}

Universidade Católica de Pelotas, Curso de Graduação em Serviço Social, Programa de Pós-Graduação em Política Social e Direitos Humanos. Pelotas, RS/Brasil.

cristinejrib@gmail.com

Translation: this article was translated by Jaqueline Micheli Pereira. 


\section{Notes}

(1) Due to conjunctural issues, the advisory work has become a Master's research project presented in the postgraduate program in Social Policy and Human Rights at Pelotas Catholic University. This was produced in partnership with the inhabitants of the territory, resulting in a dissertation written and presented in the methodological molds of militant research.

(2) Way of life and relationship with and in the environment (Lefebvre, 2001).

(3) Expression that manifests the conflict between capital and labor.

(4) In the photo we can see the Mayor of Pelotas, Municipal Secretaries, State Prosecutors, representatives of Universities and the housing residents' support group. For further information about the authorization / approval process for building new plot of lands, visit: https://www. mprs.mp.br/noticias/50756/ and http://www.pelotas.rs.gov.br/noticia/convenio-traz-solucaopara-o-loteamento-da-estrada-do-engenho.

\section{Referências}

ACSELRAD, H. (2010). Ambientalização das lutas sociais - o caso do movimento por justiça ambiental. Disponível em: <https://www.scielo.br/pdf/ea/v24n68/10.pdf>. Acesso em: 16 ago 2020.

ACSELRAD, H.; MELlO. C. C. A.; BeZERRA, G. N. (2009). O que é justiça ambiental. Rio de Janeiro, Garamond.

AL-ALAM, C. C. (2017). "Passo dos Negros". In: LONER, B. A.; GILL, L. A.; MAGALHÃES, M. O. (orgs.). Dicionário de História de Pelotas. Pelotas, Editora da UFPel.

ALVES, J. (2014). Regularização fundiária. Pelotas, 16 de outubro. 320 slides. Apresentação em Power Point.

(2017). Regularização fundiária: a cidade que temos e queremos. Pelotas, 7 de julho de. 337 slides. Apresentação em Power Point.

BAUER, M. W.; GASKELL, G. (orgs.) (2012). Pesquisa qualitativa com texto, imagem e som: um manual prático. Petrópolis/RJ, Vozes.

BOULOS, G. (2015). Por que ocupamos? São Paulo, Autonomia Literária.

BRASIL (2001). Lei n. 10.257/2001. Regulamenta os Artigos. 182 e 183 da Constituição Federal. Disponível em: http://www.planalto.gov.br/ccivil_03/leis/LEIS_2001/L10257.htm. Acesso em: 9 out 2017.

BRINGEL, B.; VARELLA, R. V. S. (2016). A pesquisa militante na América Latina hoje: reflexões sobre as desigualdades e as possibilidades de produção de conhecimentos. Revista digital de direito administrativo. Faculdade de Direito de Ribeirão Preto. Universidade de São Paulo, v. 3, n. 3, pp. 474-489. 
COGOY, C. (2017). Famílias lutam contra a remoção. Diário da Manhã, ano 39, n. 62, p. 6, 4 set.

COLL, L. (2017). Estamos sob pressão daqueles que podem: em Pelotas, comunidade sofre ameaça de remoção. Disponível em: https://www.sul21.com.br/jornal/estamos-sob-pressao-daqueles-quepodem-em-pelotas-comunidade-sofre-ameaca-de-remocao/. Acesso em: 20 set 2017.

CUNHA, G. C.; SANTOS, A. M. dos (2010). "Economia Solidária e Pesquisa em Ciências Sociais: desafios Epistemológicos e Metodológicos”. In: HESPANHA, P.; SANTOS, A. M. (orgs.). Economia solidária: questões teóricas e epistemológicas. Coimbra, Almedina.

DEFENDER (2010). Engenho será restaurado. Disponível em: http://defender.org.br/noticias/riogrande-do-sul/pelotasrs-antigo-engenho-sera-restaurado/. Acesso em: 9 set 2017.

ESTRADA DO ENGENHO (2017). Álbuns. Disponível em: https://www.facebook.com/pg/ EstradaDoEngenhoResiste/photos/?ref=page_internal. Acesso em: 8 jun 2020.

FILHO, A. E. (2017). Retirando os pobres para redistribuir os ricos - Sai já daí. Disponível em: http:// www.observatoriopelotas.com.br/2017/05/14/retirando-os-pobres-para-redistribuir-os-ricossai-ja-dai/. Acesso em: 24 nov 2017.

GALHARDO, R. (2008). Lula: crise é tsunami nos EUA e, se chegar ao Brasil, será 'marolinha'. Disponível em: https://oglobo.globo.com/economia/lula-crise-tsunami-nos-eua-se-chegar-ao-brasil-seramarolinha-3827410\#ixzz5HrkHrttU. Acesso em: 8 jun 2018.

GOOGLE Earth. (2017a). Vista aérea da Estrada do Engenho, Pelotas, de 2010. Disponível em: < https:// www.google.com/maps/@-31.77304,-52.31291,15z/data=!3m1!1e3>. Acesso em: 17 nov 2017.

(2017b). Vista aérea da Estrada do Engenho, Pelotas, de 2016. Disponível em: <https://www. google.com/maps/@-31.77304,-52.31291,15z/data=!3m1!1e3>. Acesso em: 17 nov 2017.

GUTIERREZ. E. J. B. (2001). Negros, charqueadas e olarias: um estudo sobre o espaço pelotense. Pelotas, Ed. UFPEL.

HARVEY, D. (2005). O novo imperialismo. São Paulo, Loyola.

IBGE (2017). Pelotas. Disponível em: http://cidades.ibge.gov.br/xtras/perfil.php?codmun=431440. Acesso em: 2 jul 2017.

IDEALIZA (2014). Parque UNA Pelotas. Disponível em: http://www.parqueunapelotas.com.br/site/. Acesso em: 25 nov 2017.

KOWARICK, L. (1993). A espoliação urbana. São Paulo, Paz e Terra.

KRUGER, N. R. M. (2018). O plano perfeito: da retórica sobre o direito à moradia ao Programa Minha casa Minha Vida a negação do habitar. Dissertação de mestrado. Pelotas, Universidade Católica de Pelotas.

LEFEBVRE, H. (2001). O direito à cidade. São Paulo, Centauro.

MARICATO, E. (2015). Para entender a crise urbana. São Paulo, Expressão Popular.

MARTINS, J. S. (1997). Exclusão social e a nova desigualdade. São Paulo, Paulus.

MORGAN, D. (1997). Focus group as qualitative research. Qualitative Research Methods Series 16. Londres, Sage Publications. 
MOURA. R. M. G. R de (2006). Habitação popular em Pelotas (1880-1950): entre políticas públicas e investimentos privados. Tese de doutorado. Porto Alegre, Pontifícia Universidade Católica do Rio Grande do Sul.

MUNARETTO, S. (2017). Estrada do Engenho resiste: a luta de uma comunidade pelo direito à moradia. Disponível em: http://reporterpopular.com.br/estrada-do-engenho-resiste-luta-de-umacomunidade-pelo-direito-moradia/. Acesso em: 9 set 2017.

NABUCO, A.; PRIMI, L.; NABUCO, W. (2014). Luta por um Teto. Revista Caros Amigos, jul. Entrevista Guilherme Boulos.

NETTO, J. P. (2011). Introdução ao estudo do método de Marx. São Paulo, Expressão Popular.

NIGRO, C. D. (2007). (In)sustentabilidade urbana. Curitiba, Ibpex.

OLIVEIRA, F. de (2013). Crítica a razão dualista o ornitorrinco. São Paulo, Boitempo.

PAPALÉO, M. T. (1991). "O pensamento político de Norberto Bobbio - Algumas considerações". In: RECH, H.; FREITAS, J. (orgs.). Teoria da organização nos clássicos e uma incursão na filosofia política contemporânea. Rio Grande, Editora da FURG.

PELOTAS (1968). Lei n. 1672/1968. Disponível em: http://intranet.pelotas.com.br/politica_urbana_ ambiental/planejamento_urbano/I_plano_diretor/I_plano_diretor.pdf. Acesso em: 19 maio 2018.

(1980). Lei n. 2565/80. Institui o II Plano Diretor de Pelotas. Disponível em: http://www2. camarapel.rs.gov.br/camarapel.rs.gov.br/legislacao/codigodeedificacoesplanodiretor/ Codigodeedificacoes/Planodiretor\%20revisado.pdf. Acesso em: 19 maio 2018.

PELOTAS (2008). Lei municipal n. 5.502/2008. Disponível em: http://www.pelotas.com.br/politica_ urbana_ambiental/planejamento_urbano/III_plano_diretor/lei_iii_plano_diretor/arquivos/ lei_5502.pdf. Acesso em: 5 dez 2015.

(2009). Lei municipal n. 5.603/2009. Disponível em: https://www.leismunicipais.com.br/.../ pelotas/lei.../5603/lei-ordinaria-n-5603.pdf. Acesso em: 25 jan 2015.

(2012). Lei municipal n. 5.963/2012. Disponível em: http://www.pelotas.rs.gov.br/interesse_ legislacao/leis/2012/LEI5963.pdf. Acesso em: 26 jun 2016.

PEREIRA, C. P. (2013). Proteção social no capitalismo: contribuição à crítica de matrizes teóricas e ideológicas conflitantes. Tese de doutorado. Brasília, Universidade de Brasília.

PINTO, J. V. (2016). Contribuições para estudo do "Programa Minha Casa Minha Vida" para uma cidade de porte médio, Pelotas-RS: caracterização das empresas construtoras e incorporadoras privadas e inserção urbana. Dissertação de mestrado. Pelotas, Universidade Federal de Pelotas.

PLHIS (2013a). Plano local de habitação de interesse social de Pelotas - Etapa 3: estratégias de ação. Pelotas, 3C Arquitetura e Urbanismo.

(2013b). Plano local de habitação de interesse social de Pelotas. Disponível em: <plhispelotas. blogspot.com>. Acesso em: 22 maio 2014.

REHABPEL (2018). Empreendimentos PMCMV em Pelotas [mensagem pessoal]. Mensagem recebida por<contatorafaelkruger@gmail.com> em 10 ago.

RHEINGANTZ, C. G. (2004). O charqueador. Diário Popular. Pelotas, ano 114, n. 274, p. 3, 9 jun. 
RIBEIRO, R. B. (2017). Dique [mensagem pessoal]. Mensagem recebida por <contatorafaelkruger@ hotmail.com> em 24 nov.

RIO GRANDE DO SUL (2012). Código estadual de meio ambiente. Porto Alegre, Assembleia Legislativa.

(2016). Acordo judicial firmado sobre a Ação Civil Pública n. 022/1.14.0007280-6. Disponível em: http://www1.tjrs.jus.br/busca/?tb=proc. Acesso em: 9 set 2017.

(2020). Pelotas: MP e Município assinam convênio para reassentamento de famílias e recuperação de área de preservação permanente. Disponível em: https://www.mprs.mp.br/ noticias/50756/. Acesso em: 8 jun 2020.

ROSENTHAL, M. D.; GONÇALVES, E. A. (2014). Marambaia: história, memória e poética. Disponível em: https://periodicos.ufpel.edu.br/ojs2/index.php/Arte/article/view/4810/3592. Acesso em: 9 set 2017.

SAQUET, M. A.; SILVA, S. S. (2008). Milton Santos: concepções de geografia, espaço e território. Ver. Geo UERJ. Rio de Janeiro, v. 2, n. 18, pp. 24-42.

VAINER, C. (2013). A cidade do pensamento único: desmanchando consensos. Petrópolis, Vozes. 